\title{
Strategi Promosi Startup (pada Aplikasi Bakat.Online Antara Agent Talent dalam Mempersuasi Masyarakat Menjadi Talent)
}

\author{
Gilang Frihady $^{1}$, Sri Rahardian Mukjizat Sakti ${ }^{2}$, Shulhuly Ashfahani ${ }^{3}$ \\ ${ }^{1,2,3}$ Sekolah Tinggi Ilmu Komunikasi Indonesisa Maju \\ Email correspondent: gilangfrihady@gmail.com
}

\begin{abstract}
Abstrak
Penelitian ini menganalisis kegiatan strategi promosi yang dijalankan Aplikasi bakat.online. Strategi promosi ini meliputi bauran promosi yang ditujukan kepada pihak Agent, Studio-studio, dan masyarakat sebagai target konsumen akhir (end user). Penelitian ini bertujuan untuk menganalisis dan mendalami mengenai strategi promosi bakat.online pada jasa Aplikasi dalam upaya mempersuasif masyarakat untuk menjadi Talent.Penelitian ini menggunakan pendekatan deskriptif kualitatif, sehingga peneliti mampu mendeskripsikan sedalam-dalamnya mengenai persoalan strategi promosi yang telah digunakan oleh bakat.online dengan menggunakan parameter efektifitas komunikasi dalam berpromosi. Peneliti juga menganalisis mengenai strategi promosi yang mampu membangun kesetiaan jasa sebagai wujud upaya establishing acceptance oleh bakat.online. Peneliti menggunakan pengumpulan data melalui wawancara, observasi. Hasil dari penelitian ini adalah bakat.online telah menggunakan 2 (dua) strategi promosi, yaitu: pull strategy meliputi: bidang publisitas, sales promotion, dan personal selling dan push strategy meliputi: relationship of marketing sebagai konsep bisnis business to business. Kesimpulannya strategi promosi aplikasi, memiliki peranan yang sangat penting bagi bakat.online dalam menjalankan kegiatan bisnis Talent yang bertujuan untuk meningkatkan kesadaran masyarakat terhadap jasa "Talent" Walaupun upaya Bakat.online dalam mempersuasif masyarakat menjadi talent melalui push-strategy masih dapat ditingkatkan, sehingga upaya persuasif melalui komunikasi efektif dalam berpromosi masih tetap sangat diperlukan.
\end{abstract}

Kata Kunci: agent, bakat.online, promosi, talent.

\begin{abstract}
This study analyzes promotional strategy activities carried out by talent. online applications. This promotion strategy includes a promotional mix aimed at the Agent, Studios, and the public as the target end-user (end-user). This study aims to analyze and explore the talent promotion strategy. Online in Application services to persuade the public to become a Talent. This research uses a qualitative descriptive approach so that researchers can describe deeply the issue of promotional strategies that have been used by talent. online using the parameters of the effectiveness of communication in the promotion. Researchers also analyzed promotional strategies that we're able to build service loyalty as a form of establishing acceptance by talent. online. Researchers use data collection through interviews, observations. The results of this study are talent. online has used 2 (two) promotional strategies, namely: pull strategy includes: the field of publicity, sales promotion, and personal selling, and push strategy includes: relationship of marketing as a business to the business concept. In conclusion, the application promotion strategy has a very important role for talent. Online in running Talent business activities which aims to increase public awareness of "Talent" services. Although Talent. online's efforts in intensifying the community into talent through push-strategy can still be increased so that efforts persuasion through effective communication in promotion is still very much needed.
\end{abstract}

Keywords: agent, talent, online, promotion, talent. 


\section{Pendahuluan}

Strategi promosi akan berjalan secara optimal bila didukung perencanaan yang terstruktur dengan baik. Bauran promosi (promotion mix) juga disebut bauran komunikasi pemasara (marketing communication mix) perusahaan merupakan paduan spesifik iklan, promosi penjualan, hubungan masyarakat, penjualan personal, dan sarana pemasaran langsung yang digunakan perusahaan untuk mengkomunikasikan nilai pelanggan secara persuasif dan membangun hubungan pelanggan. ${ }^{1}$

Promosi pada hakekatnya adalah suatu komunikasi pemasaran, artinya aktifitas pemasaran yang berusaha menyebarkan informasi, mempengaruhi atau membujuk, dan atau mengingatkan pasar sasaran atas perusahaan dan produknya agar bersedia menerima, membeli, dan loyal pada produk yang ditawarkan perusahaan yang bersangkutan. ${ }^{2}$

Keberhasilan strategi pemasaran dipengaruhi oleh beberapa faktor, salah satunya yaitu dengan memilih promosi yang tepat dalam memasarkan jasa. Konsumen dan perusahaan dapat digambarkan sebagai sebuah sistem yang masing-masing memiliki maksud dan tujuan yang hendak dicapai. Posisi saat ini dengan tujuan yang hendak dicapai menciptakan suatu gap yang disebut sebagai kebutuhan. Peran dari komunikasi pemasaran adalah memberikan arti keseluruhan penawaran produk kepada konsumen sehingga konsumen dapat memenuhi maksudnya sekaligus perusahaan bisa mencapai tujuannya. Kegiatan pemasaran tidak akan berlangsung bila tidak ada komunikasi. Komunikasi dapat membantu produsen menawarkan produknya dan mempengaruhi konsumen agar menggunakan produk yang ditawarkan. ${ }^{3}$

Berdasarkan informasi penawaran, konsumen dapat memperoleh produk sesuai dengan kebutuhan dan keinginan. Komunikasi pemasaran dapat dilihat sebagai pesan terencana dari perusahaan dan organisasi yang dibuat dan disebarluaskan untuk mendukung tujuan dan strategi pemasaran mereka. ${ }^{4}$

Istilah startup sering dikaitkan dengan bisnis yang baru dirintis atau baru berkembang, biasanya merujuk pada semua perusahaan yang belum lama beroperasi dan identik dengan bisnis yang berbau teknologi. Neil Blumenthal, cofounder dan co-CEO dari Warby Parker mengatakan bahwa startup adalah suatu perusahaan yang bekerja untuk memecahkan masalah di mana solusinya tidak jelas dan kesuksesan tidak dijamin. Adora Cheung cofounder dan CEO dari Homejoy, salah satu hottest U.S Startups di tahun 2013 mengatakan bahwa startup is a state of mind (startup adalah keadaan pikiran. ${ }^{5}$

Atribut kunci dari startup adalah kemampuan untuk bertumbuh, di mana startup adalah sebuah perusahaan yang dirancang untuk bertumbuh secara cepat. startup berfokus pada pertumbuhan yang tidak dibatasi oleh geografi, hal inilah yang membedakannya dengan small business atau bisnis kecil. internet merupakan salah satu faktor penyebab pesatnya pertumbuhan startup. Menurut Alves, internet telah menjadi "kebutuhan" masyarakat saat ini. Internet membawa perubahan revolusioner, menciptakan lingkungan baru yang menandai era transisi dari masyarakat industrial menuju masyarakat digital atau knowledge-based society. ${ }^{6}$

Bakat.online merupakan sebuah aplikasi yang berguna untuk mewadahi para talent yang mempunyai bakat dibidang seni dapat mempermudah usaha dalam memilih talent tanpa harus mengeluarkan gaji bulanan. Dengan mudahnya mengakses melalui pengunduhan di playstore maka masyarakat mudah mencari melalui media internet untuk menyalurkan bakatnya lewat aplikasi Bakat.Online yang menjadi platform bagi para talent agar client dengan mudah untuk mencari talent yang diinginkan. Dalam platform tersebut sudah mencakup semua yang dibutuhkan talent dan client sehingga mempermudah dalam melakukan pencarian detail biodata ataupun kontak person yang tersedia di dalam aplikasi tersebut.

Beberapa agent telah bekerja sama dengan Bakat.Online dimana masing-masing agent menangani sesuai bakat dari talent, agent Midolovita yang menagani peminatan talent dibidang aktris, aktor dan singer, Ibank management yang menangani peminatan talent dibidang talent dance, aktor, 
aktris, dan model, republic Gila management yang menangani peminatan talent dibidang standup comedy, dan AuraSekar winda management yang menangani peminatan talent dibidang make up artis, dan model.

Agent yang berhasil mengajak talent untuk bergabung ke Bakat.Online akan di arahkan pembuatan profile foto, video, cara mengisi data diri, mengenai pendapatan hasil yang di terima oleh talent hingga tahap transaksi penggunaan jasa lewat chatting yang tersedia di aplikasi Bakat.Online, setelah data sudah lengkap di isi oleh talent pihak Bakat.Onlie akan meng upload data talent supaya talent mendapatkan pekerjaan lewat aplikasi Bakat.Online.

Bakat.online mempunyai beberapa media promosi untuk meningkatkan daya jual penggunaan aplikasi adapun media yang di gunakan yaitu youtube, instagram, whatsapp. dikarnakan yang seperti kita ketahui media- media tersebut mempunyai pengguna yang cukup banyak dalam mengakses media tersebut sehingga aplikasi bakat. online perlahan namun pasti dapat di kenal oleh masyarakat di Indonesia.

Selain melalui media online strategi promosi bakat.online juga melakukan pendekatan secara langsung kepada masyarakat seperti melakkukan pertemuan kepada management-management, dan Studio-Studio sebagai patner dan mengadakan event dalam kategori seni dimana mengundang banyak masyarakat yang mempunyai talenta sehingga menjadi moment yang pas dan tepat sasaran dalam mempromosikan bakat.online. Namun ada agent yang kurang memahami mengenai pengunaan aplikasi dan kurangnya agent dalam memotivasi talent serta kurangnya pengetahuan dari agent dalam memberitahu seputar Bakat.Online.

Diharapkan agent dengan jasa dan pelayanan bakat.online tentunya mempermudah talent yang belum mengerti dengan pemakaian aplikasi bakat.online agar mampu mengoprasikan layanan yang ada di aplikasi bakat.online dengan mandiri. Keuntungan dari penggunaan apikasi bakat.online bisa mempermudah talent mendorong untuk berkontribusi terhadap pekerjaan yang dilakukan demi mencapai tujuan yang diinginkan.

Dengan permasalahan di atas maka perlu mempersiapkan Actionplan. Hal yang pertama tentang product knowledge (pengetahuan tentang produk) Kerumitan yang terjadi disebabkan tidak adanya kemudahan panduan mengenai produk yang harusnya di sediakan oleh pihak aplikasi. Tidak adanya bagian khusus yang merancang system sehingga informasi sulit tersampaikan kepada agent dan talent. Tidak adanya panduan yang tersedia di aplikasi membuat para agent kesulitan untuk memperoleh informasi apalagi terbatasnya costumer service. Dengan menjamurnya smartphone seharusnya sangat tepat waktu dalam memperkenalkan aplikasi yang di unggulkan sehingga memiliki peluang yang lebih luas dengan dukungan kemitraan bersama agent. Sistem informasi yang minim membuat segala arus informasi tidak tersampaikan dengan baik. Menyiapkan segala strategi guna mengetahui bagaimana cara memulai, menjalankan dan mengelola bisnis. Untuk menjalankan bisnis di perlukan rancangan action plan yang sesuai dengan core bisnis. Berdasarkan penjelasan diatas, peneliti memiliki alasan untuk mengangkat topik pada persoalan strategi promosi yang dilakukan oleh Bakat.Online sebagai upaya mempersuasif masyarakat untuk menjadi talent dalam aplikasi tersebut.

Tujuan dari penelitian ini adalah untuk untuk mengetahui Strategi Promosi Startup pada aplikasi Bakat.Online dalam upaya mempersuasif masyarakat menjadi talent.

\section{Metode}

Penelitian ini merupakan penelitian deskriptif dengan pendekatan kualitatif. Penelitian deskriptif yaitu penelitian yang bertujuan membuat deskripsi secara sistematis, faktual, dan akurat tentang fakta-fakta serta sifat tertentu. Pendekatan kualitatif yang dimaksud sebagai prosedur penelitian yang menghasilkan data deskriptif berupa kata-kata tertulis atau lisan dari orang-orang dan perilaku yang dapat diamati. ${ }^{7}$ 
Key informan merupakan seseorang yang memang ahli di bidang yang akan diteliti, sementara informan merupakan orang-orang yang relevan dengan bidang yang diteliti, dimana keterangan dari informan diperoleh untuk mengecek kebenaran atau memperkaya informasi dari key informan, pencarian key informan dan informan harus selektif, sehingga upaya penggalian data bisa dilakukan secara maksimal. ${ }^{8}$

Lokasi penelitian dilakukan di Jl. Raya Pkp No.11, RT.8/RW.8, Klp. Dua Wetan, Kec.Ciracas, Kota Jakarta Timur, Daerah Khusus Ibukota Jakarta 13730. Waktu pelaksanaan penelitian data di lakukan pada tanggal 07 maret sampai 09 Juni 2019.

Sumber primer adalah sumber data yang secara langsung memberikan data kepada pengumpul data, Sumber primer ini berupa catatan hasil wawancara yang diperoleh melalui wawancara yang peneliti lakukan. Selain itu, peneliti juga melakukan observasi lapangan dan mengumpulkan data dalam bentuk catatan tentang situasi dan kejadian di perusahaan. ${ }^{9}$

Sumber data sekunder merupakan sumber data yang tidak memberikan informasi secara langsung kepada pengumpul data. Sumber data sekunder ini dapat berupa hasil pengolahan lebih lanjut dari data primer yang disajikan dalam bentuk lain atau dari orang lain. ${ }^{10}$ Data sekunder diperoleh melalui studi kepustakaan, yaitu mengumpulkan data melalui literatur yang berhubungan dengan penelitian ini, seperti buku-buku, skripsi terdahulu, kamus, website, dan artikel-artikel yang terkait dengan penelitian ini.

Observasi dilakukan untuk mendekatkan peneliti ke orang-orang yang ditelitinya dan ke situasi atau lingkungan mereka yang sebenarnya. Dan peneliti dapat masuk ke lingkungan yang ditelitinya atau yang dikenal dengan observasi partisipatif. Pada observasi ini, peneliti mengamati peristiwa, kejadian, pose, dan sejenisnya disertai dengan daftar yang perlu di observasi. ${ }^{11}$

Wawancara adalah hasil bersamaseorang peneliti dan satu atau lebih anggota. Anggota adalah peserta aktif yang wawasan, perasaan, dan kerjasamanya menjadi bagian penting dari proses pembahasan yang mengungkapkan makna subjektif. Wawancara melibatkan rasa berbagi pengalaman maupun latar belakang untuk mendorong keterbukaan dari informan. ${ }^{12}$ Jenis wawancara mendalam, non terstruktur kepada talent dan agent. alasannya adalah untuk mendapatkan inforamasi tentang fakat fakta permsalahan yang muncul di dalam pelaksaan strategi promosi startup pada bakat.online antara agent dan talent dalam upaya mempersuasif masyarakat menjadi talent.

Metode dokumentasi adalah metode pengumpulan data yang datanya diperoleh dari buku, internet, atau dokumen lain yang menunjang penelitian yang dilakukan. Dokumen merupakan catatan mengenai peristiwa yang sudah berlalu. peneliti mengumpulkan dokumen yang dapat berupa tulisan, gambar, atau karya-karya monumental dari seseorang Sugiyono, untuk mendapatkan dan mengetahui data-data dan informasi yang berkaitan dengan permasalahan strategi promosi startup pada bakat.on line antara agent dan talent dalam upaya mempersuasi masyarakat menjadi talent. Teknik pemilihan key-informan yang telah digunakan dalam penelitian ini adalah purposive-sampling terhadap owner di bakat.dalam meningkatkan minat masyarakat teknik pemilihan informan secara purposive adalah: ${ }^{13}$

Triangulasi data sumber adalah Suatu teknik pengecekan kredibilitas data yang dilakukan dengan memeriksa data yang didapatkan melalui beberapa sumber". Teknik analisis triangulasi sumber ini merupakan suatu proses menganalisis jawaban dengan meneliti kebenaran dengan data empiris (sumber data lainnya) seperti keterangan hasil wawancara dengan dokumen tertulis dengan cara cross- check kekonsistenan atau kesahihan data dan informasi tersebut. Ataupun dengan cara membandingkan atau mengecek ulang derajat kepercayaan suatu informasi yang diperoleh dari satu informan yang berbeda melalui cross- check antara jawaban satu key-imforman dengan informan lainnya. ${ }^{14}$

Tujuan penggunaan teknik analisis triangulasi data ini, adalah bukan sekedar mencari suatu kesahihan fakta yang terkait dengan pelaksanaan kegiatan strategi promosi startup pada aplikasi, 
melainkan lebih pada usaha peningkatan kepercayaan dan ketajaman pemahaman secara utuh terhadap segala persoalan data-informasi yang sedang dikaji yaitu sebagai bentuk usaha perusahaan bakat.online dalam mempersuasi masyarakat untuk menjadi talent.

\section{Hasil dan Pembahasan \\ Strategi Promosi Startup pada aplikasi bakat.online dalam upaya mempersuasi masyarakat menjadi talent}

Strategi promosi pada jasa aplikasi ini, merupakan bentuk perencanaan kegiatan komunikasi yang strategis yang dilakukan oleh bakat.online dalam membangun kegiatan promosi pada jasa "talent' yang baik, sehingga kedepannya implementasi kegiatan bisnis aplikasi pada jasa "talent" ini dapat berjalan efektif, efisien, dan tepat sasaran.

Kegiatan strategi promosi pada jasa 'talent' yang dijalankan oleh agent sebagai komunikator harus didukung juga dengan pengetahuan tentang isi dari bakat.online (product of knowledge) yang luas, dan pengalaman yang cukup, serta kemampuan dalam berkomunikasi yang baik terkait pelaksanaan kegiatan promosi pada jasa 'talent'" yang diterapkan di bakat.online sebagai bentuk usaha dalam mempersuasi masyarakat untuk menjadi talent. Strategi promosi pada jasa 'talent' 'yang dijalankan oleh aplikasi bakat.online, bertujuan untuk memudahkan para karyawan dalam memasarkan dan mengarahkan masyarakat sebagai talent agar dapat memilih, menentukan, dan melakukan pilihan terhadap jasa 'talent", sehingga kegiatan promosi ini kedepannya mampu menjaga dan menjamin kelangsungan hidup kegiatan bisnis aplikasi bakat.online jangka panjang.

Berdasarkan hasil wawancara di atas, menjelaskan bahwa aplikasi bakat.online dalam menjalankan kegiatan bisnis pada jasa talent ini, hanya menggunakan kegiatan promosi melalui publisitas, personal selling, dan sales promotion, dengan pihak masyarakat sebagai target bisnisnya. Berbagai bentuk kegiatan promosi pada jasa talent. selama ini faktanya masih belum berjalan dengan efektif, dikarenakan aplikasi bakat.online dalam menjalankan kegiatan bisnis talent masih sering mengalami kendala, baik dari segi pull strategi, pull promosi, dan 3 strategi komunikas. To secure understanding, to motivating action, to erstablish acceptance di karnakan tidak adanya panduan dalam aplikasi tersebut maka pengguna jasa sulit untuk menjalankan aplikasi bakat.online dengan baik.

Pada tahap awal bakat.online sebagai bisnis yang bergerak di bidang jasa, telah menjalankan strategi promosi melalui berbagai kegiatan promosi, seperti: penjualan tatap muka, publitas, personal selling yang didukung dengan pendekatan komunikasi langsung, baik secara luas, maupun secara personal kepada masyarakat dengan tujuan menciptakan, mempengaruhi, dan menanamkan pemahaman tentang bakat.online sebagai kebutuhan manusia, sehingga proses komunikasi ini mampu menciptakan rasa saling pengertian, dan berkelanjutan atas pesan promosi daninformasi yang diberikan oleh aplikasi kepada masyarakat sebagai talent. ini telah mampu menjalankan roda kegiatan bisnis startup pada jasa aplikasi di bakat.online

Berdasarkan hasil wawancara di atas bahwa kegiatan promosi pada aplikasi melalui publisitas, personal selling, sales promotion, di bakat.online ini, bertujuan untuk mendapatkan keuntungan semata dengan cara mempersuasi masyarakat agar menjadi "talent" serta menjalin hubungan kerja sama business to business dengan pihak agent, Studio sebagai rekanan sebagai mitra dan target bisnis untuk meningkatkan jumlah jaringan kerja sama bisnis pada aplikasi bakat.online dengan harapan mampu menambah Suatu hubungan kerja sama business to business pada jasa aplikasi antara agent dan Studio sekanan sebagai target bisnis ini, merupakan strategi promosi aplikasi bakat.online yang utama dan penting sebagai usaha untuk mempersuasi masyarakat agar menjadi talent.

\section{Publisitas}

Publistas merupakan salah satu bentuk kegiatan promosi umumnya sering digunakan oleh 
aplikasi bakat.online dalam menjalankan kegiatan promosi pada jasa "talent" Bentuk kegiatan publitas yang terdapat di aplikasi bakat.online ini, masih tergolong minim dan belum dapat berjalan dengan baik, apabila dibandingkan dengan aplikasi lainnya di Indonesia jarang sekali ditemui dan diketahui oleh masyarakat.

Kegiatan publisitas pada jasa "talent" di aplikasi bakat.online ini berfungsi sebagai media relations yang dipergunakan oleh aplikasi bakat.online dengan tujuan untuk menginformasikan, dan menyebarluaskan segala bentuk berita dan informasi tentang kegiatan bisnis aplikasi pada jasa "talent" sebagai bentuk penghargaan atas kinerja dan prestasi atas hasil jasa "talent", yang dapat disebarluaskan kepada masyarakat luas melalui media online.

Berdasakan hasil wawancara di atas, menjelaskan bahwa kegiatan publisitas yang dipergunakan oleh aplikasi bakat.online dalam mempromosikan jasa "talent" ini, dapat dikatakan belum berhasil, meskipun kegiatan promosi publisitas pada jasa "talent" ini bertujuan untuk membangun citra positif dan memperkuat positioning bakat.online di mata masyarakat, dikarenakan kegiatan publisitas melalui media online yang dipergunakan oleh aplikasi bakat.online. bisnis ini memiliki segmentasi khusus, sehingga hal tersebut mempengaruhi bagi para masyarakat untuk mengetahui tentang segala bentuk kegiatan promosi pada aplikasi bakat.online.

\section{Penjualan Tatap Muka (Personal Selling)}

Bentuk kegiatan promosi penjualan tatap muka pada jasa "talent" aplikasi bakat.online ini, merupakan bentuk kegiatan proses interaksi komunikasi promosi yang dilakukan oleh karyawan bakat.online kepada masyarakat secara tatap muka (face to face communication) Bentuk kegiatan komunikasi promosi pada jasa "talent" yang dilakukan oleh karyawan bakat.online ini, diharapkan proses interaksi komunikasi yang terjadimampu memberikan suatu pemahaman atas informasi dalam bentuk penawaran dan presentasi pada jasa "talent" yang ditawarkan kepada masyarakat sebagai target akhir dengan tujuan untuk meningkatkan jumlah penjualan dan pendapatan jasa "talent" pada aplikasi bakat.online.

Kegiatan promosi pada jasa "talent" di aplikasi bakat.online melalui promosi penjualan ini, dapat dikatakan tidak dapat berjalan efektif dan efisien dalam meningkatkan jumlah penjualan jasa "talent", dikarenakan sumber daya manusia (SDM) yang kurang memadai, dan intensitas pelaksanaan penjualan tatap muka ini akan memakan banyak waktu dan tenaga, meskipun kegiatan promosi penjualan tatap muka ini pada jasa "talent" ini tidak bisa dipungkiri mampu menciptakan komunikasi yang efektif dengan menanamkan rasa saling pengertian, kesepahaman, dan menciptakan motivasi atas pesan promosi yang disampaikan oleh karyawan bakat.online kepada masyarakat untuk menjadi talent, sehingga kegiatan promosi pada jasa "talent" ini diharapkan kedepannya mampu berjalan baik dan berkelanjutan menjadi suatu kegiatan yang positif bagi aplikasi bakat.online tersebut.

\section{Promosi Penjualan (Sales Promotion)}

Aplikasi bakat.online dalam menjalankan kegiatan promosi penjualan pada jasa "talent" ini, bertujuan untuk memberikan suatu nilai tambah (insentif) bagi karyawan bakat.online sebagai tenaga penjualan jasa kepada pihak distrbutor (perantara), dan masyarakat sebagai end user. Aplikasi bakat.online menggunakan tenaga memiliki tujuan utama untuk menciptakan pemahaman dan penjelasan yang lebih dalam, sehingga proses penyammpaian pesan yang diberikan mudah dimengerti oleh masyarakat terkait jasa "talent". Kegiatan promosi penjualan secara umum dapat dibedakan menjadi 2 (dua) bagian, yaitu Promosi penjualan yang berorientasi kepada konsumen (consumeroriented sales promotion), Promosi penjualan yang berorientasi kepada perdagangan (trade- oriented sales promotion). ${ }^{14}$

Berdasarkan penjelasan di atas, menjelaskan bahwa aplikasi bakat.online dalam mejalankan 
kegiatan promosi penjualan pada jasa "talent" memiliki 2 (dua) target bisnis, yaitu: masyarakat sebagai talent, dan pihak rekanan bisnis. Alasan aplikasi bakat.online dalam menjalankan kegiatan promosipenjualan ini, dikarenakan masyarakat sebagai konsumen tidak memiliki loyalitas pada suatu jasa "talent" dan masyarakat lebih peka kepada insentif yang ditawarkan suatu jasa "talent". Kedua, terdapat kecenderungan aplikasi bakat.online memiliki positioning yang lebih kuat, dan memiliki positioning aplikasii lain, sehingga mereka dapat lebih menuntut produsen untuk memberikan lebih banyak promosi penjualan dan insentif lainnya.

\section{Strategi Promosi "Push Strategy"}

Strategi promosi "push strategy" merupakan kegiatan bisnis aplikasi pada jasa "talent" di aplikasi bakat.online yang sangat penting dilakukan oleh pimpinan, dan para karyawan bakat.online untuk mampu menanamkan rasa saling pengertian, dan kesepahaman atas pesan promosi yang diberikan kepada talent dengan menciptakan rasa memotivasi dengan tujuan menjaga keberlangsungan kegiatan bisnis aplikasi pada jasa "talent" dalam usaha untuk mempersuasi masyarakat agar menjadi talent. Strategi promosi "push strategy" ini dapat diterapkan dalam menjalankan kegiatan promosi aplikasi bakat.online, realitanya strategi promosi push tersebut dapat diimplementasikan oleh para karyawan bakat.online dengan cara melakukan pendekatan komunikasi interpersonal antara karyawan dengan para agent dan studio-studio rekanan.

Berdasarkan hasil wawancara aplikasi bakat.online dalam menjalankan kegiatan relationship marketing kepada pihak kedua ini, memiliki hubungan kontrak bisnis kerja sama sebagai bentuk usaha aplikasi bakat.online dalam menjalankan strategi promosi pada jasa "talent" untuk mempersuasi masyarakat agar menjadi talent.

Sebuah perusahaan dalam pengelolaan kegiatan pemasaran sangat menekankan relationship marketing adalah karena adanya pemahaman bahwa mempertahankan pelanggan memerlukan biaya yang lebih murah, daripada upaya mendapatkan pelanggan baru. ${ }^{15}$

Alasan bakat.online menjalankan kegiatan relationship of marketing ini, dikarenakan bakat.online akan lebih mudah adanya perjanjian kerjasama dengan rekan bisnis dan masyarakat secara langsung sebagai end user. Oleh karena itu pelaksanaan strategi komunikasi promosi antara aplikasi bakat.online dengan agent dan studio-studio rekanan telah memiliki perjanjian kerjsama binis dengan perusahaan bisnis lainnya, sebagai bentuk strategi promosi mendorong "push strategy". aplikasi bakat.online dalam menjalankan strategi promosi ini tidak akan berhasil, apabila tidak didukung dengan aplikasi strategi komunikasi promosi yang baik.

Berdasarkan penjelasan kegiatan strategi promosi pada aplikasi bakat.online, agar strategi promosi dapat berjalan efektif, maka aplikasi startup membutuhkan adanya suatu perencanaan dan manajemen komunikasi yang baik, agar tujuan dalam berkomunikasi dapat berjalan dengan baik, maka startup membuat suatu strategi komunikasi yang singkat dan efektif untuk melaksanakan implementasi strategi promosi pada aplikasi bakat.online ini dalam usaha mempersuasi masyarakat agar menjadi talent.

Berdasarkan penjelasan di atas, Berikut ini peneliti akan memberikan pembahasan secara mendalam terkait beberapa kasus temuan di lokasi penelitian di aplikasi bakat.online tentang strategi promosi pada aplikasi bakat.online dalam usaha mempersausi masyarakat untuk menjadi talent yang muncul di lokasi penelitian selama ini.

Pada penelitian kali ini peneliti juga melakukan pembahasan secara mendalam tentang kegiatan promosi aplikasi bakat.online strategi promosi pada bakat.online yang dapat dibagai ke dalam tahapan 3 (tiga) kluster komunikasi-promosi yang efektif. 


\section{Strategi Komunikasi-Promosi pada bakat.online "dalam Pemahaman "To Secure Understanding”}

Strategi komunikasi promosi pada aplikasi yang diterapkan oleh bakat.online dalam menjalankan kegiatan komunikasi bisnis startup selama ini, digunakan oleh para karyawan marketing untuk menciptakan rasa saling pengertian, dan kesepahaman antar kedua belah pihak melalui proses interaksi komunikasi yang dijalin antara perusahaan aplikasi dengan masyarakat sebagai talent.

Berdasarkan hasil penelitian di atas, menjelaskan bahwa aplikasi pada bakat.online dalam kegiatan proses interaksi komunikasi promosi pada faktanya masih mengalami kendala dalam menjalankan proses penyampaian pesan promosi kepada masyarakat. Strategi komunikasi-promosi pada bakat.online ini, merupakan suatu bentuk implementasi atas kegiatanpromosi pada aplikasi bakat.online yang bertujuan menginformasikan,membujuk, dan menyebarluaskan pesan promosi terkait informasi pada bakat.online kepada masyarakat sebagai talent.

Kegiatan promosi pada aplikasi yang dijalankan bakat.online ini, bertujuan untuk menciptakan suatu proses hubungan komunikasi transaksional yang terjalin antara karyawan bakat.online dengan masyarakat sebagai talent, sehingga masyarakat mampu memahami dan termotivasi atas apa maksud dan tujuan dari pesan promosi, sehingga kegiatan promosi pada aplikasi bakat.online ini mampu menjadi suatu kegiatan promosi yang berkelanjutan dan bermanfaat bagi aplikasi bakat.online itu sendiri, maupun masyarakat sebagai talent.

Proses interaksi komunikasi yang terjalin antara aplikasi bakat.online dengan agent dalam menjalankan kegiatan bisnis talent selama ini, faktanya memang tidak berjalan dengan baik dan efektif. Proses interaksi komunikasi pada aplikasi bakat.online dalam menjalankan kegiatan promosi jasa "talent" ini, ternyata masih sering kali mengalami kendala, gangguan, bahkan kegagalan dalam berkomunikasi, sehingga strategi promosi tidak dapat berjalan sesuai yang diterapkan sebelumnya. Di karnakan tidak adanya panduan atau tutorial yang di sediakan oleh aplikasi bakat.online.

\section{Strategi Komunikasi-Promosi pada Aplikasi dalam Pemahaman “to Motivating Action”}

Bakat.online dalam menyampaikan, menyebarluaskan dan mempengaruhi informasi jasa talent kepada masyarakat, sepatutnya para karyawan bakat.online harus juga mampu memotivasi masyarakat untuk menjadi talent.

Keberhasilan bakat.online dalam menjalankan strategi promosi pada jasa aplikasi saat ini, sesungguhnya tidak lepas dari kemampuan para karyawan bakat.online sendiri dalam menyampaikan pesan promosi kepada masyarakat sebagai talent untuk memotivasi, mempersuasi, bahkan mempengaruhi masyarakat agar menjadi talent, akan tetapi realitanya berbagai kegiatan promosi pada aplikasi yang telah dijalankan oleh bakat.online, tidak berjalan dengan baik sesuai rencana.

Kegiatan promosi pada aplikasi yang dijalankan oleh bakat.online saat ini, harus mampu memotivasi masyarakat untuk menjadi talent sebagai tolak ukur dan kunci keberhasilan usaha bakat.online dalam menjalankan kegiatan promosi akan tetapi realitanya pelaksanaan kegiatan promosi bakat.online pada aplikasi ini, tidak dapat berjalan dengan baik sesuai prosedur kegiatan promosi yang ditetapkan tidak adanya tutorial atau panduan mengenai penggunaan aplikasi. Hal ini dikarenakan para karyawan bakat.online dan agent mengalami kegagalan dalam berkomunikasi mempersuasi masyarakat agar menjadi talent.

\section{Strategi Komunikasi-Promosi pada aplikasi dalam Pemahaman "to Establish Acceptance"}

Strategi promosi pada aplikasi yang telah digunakan oleh bakat.online selama ini, merupakan pedoman perusahaan startup dalam menjalankan kegiatan promosi pada bakat.online. Penyelenggara kegaiatan promosi pada bakat.online haruslah mampu menjamin adanya suatu tahap keberlanjutan atas kegiatan promosi dalam jangka panjang, selama proses kegiatan komunikasi promosi ini berlangsung, 
sehingga kegiatan promosi pada bakat.online ini ke depannya mampu menanamkan kesadaran, dan menciptakan loyalitas terhadap jasa talent yang ditawarkan kepada masyarakat untuk menjadi talent. Konsep loyalitas pada bakat.online ini berkaitan erat dengan perilaku masyarakat sebagai talent dalam melakukan pemillihan, penentuan, dan pengguna aplikasi.

Aplikasi bakat.online dalam menjalankan kegiatan strategi promosi pada jasa talent ini, seharusnya memiliki suatu tujuan promosi yang hendak dicapai. Suatu tahap pencapaian keberhasilan dalam menjalankan kegiatan promosi pada bakat.online ini, dapat dilihat dari masyarakat sebagai pengguna aplikasi telah menerima atas pesan kegiatan promosi untuk mempersuasi masyarakat menjadi talent.

Berdasarkan hasil penelitian di atas membuktikan bahwa aplikasi bakat.online dalam menjalankan kegiatan strategi promosi pada jasa "talent" ini, umumnya bertujuan untuk mendapatkan keuntungan bisnis talent semata dalam jangka panjang. Oleh karena itu aplikasi bakat.online berusaha menciptakan suatu kegiatan promosi pada jasa "talent" dengan cara mengamankan atau menjaga untuk menciptakan adanya suatu keberlanjutan Akan tetapi realitanya aplikasi bakat.online belum mampu menjalankan kegiatan promosi pada jasa "talent" ini, dikarenakan aplikasi bakat.online tidak menampilkan cara penggunaan aplikasi dengan baik.dari tutorial, ataupun panduan yang berada di dalam aplikasi. Mangkanya masyarakat kesulitian dalam penggunakan aplikasi dengan baik.

Berdasarkan ketiga tahapan strategi komunikasi-promosi pada aplikasi yang dijalankan oleh bakat.online ini, diharapkan kedepannya proses interaksi komunikasi yang terjalin antara agent dengan masyarakat dapat diterima dan dimengerti dengan baik, kemudian setelah pesan promosi pada aplikasi udah dapat diterima den dimengerti dengan baik oleh masyarakat sebagai talent, maka karyawan aplikasi sebagai komunikator dituntut juga untuk dapat membina kegiatan promosi pada aplikasi ini, sehingga pesan promosi tersebut dapat dimotivasikan kembali menjadi suatu kegiatan yang positif dan bermanfaat bagi aplikasi bakat.online tersebut.

\section{Kesimpulan}

Berdasarkan data dan paparan hasil kegiatan penelitian yang diperoleh dan telah disajikan oleh peneliti dalam bab IV di atas, maka peneliti dapat memberikan beberapa kesimpulan yang diantaranya adalah Strategi promosi memiliki peranan yang sangat penting bagi bakat.online telah menggunakan 2 (dua) konsep strategi promosi pada aplikasi sebagai bentuk usaha mempersuasif masyarakat untuk menjadi talent, yaitu: pertama, pull strategy dengan target bisnis b2c (business to costumer). Konsep strategi promosi pull startegy ini, dapat diimplementasikan oleh bakat.online melalui 3 (tiga) bentuk kegiatan promosi yaitu: publisitas, promosi penjualan, dan penjualan tatap muka. Push strategy dengan target bisnis $\mathrm{b} 2 \mathrm{~b}$ (business to business). Konsep strategi promosi push strategy ini, dapat diimplementasikan oleh bakat.online melalui kegiatan relationship of marketing dengan agent-agent dan studio- studio rekanan sebagai target bisnis. Pelaksanaan kegiatan komunikasi dalam strategi komunikasi promosi Bakat.online pada aplikasi ini masih sering mengalami persoalan, dan kendala dalm berkomunikasi, seperti: para karyawan bakat.online masih memiliki keterbatasan dalam berkomunikasi para karyawan bakat.online dalam menciptakan rasa saling pengertian dan kespahaman makna pesan promosi, kurang mampu memotivasi masyarakat dalam menciptakan komunikasi yang persuasif masyarakat agar menjadi Talent, sehingga proses interaksi komunikasi promosi belum mampu menciptakan rasa keberlanjutan atas pesan promosi Aplikasi ini juga menjadi alasan kurang berhasilnya bakat.online dalam memberitahukan, mempresentasikan, menjelaskan tentang informasi, dalam kegunaan aplikasi dengan baik. 


\section{JIKOM \\ Jurnal Ilmiah Komunikasi}

Volume 12, No.03, November. 2020

\section{References}

1. Kotler, P. \& Armstrong G. Prinsip-Prinsip Pemasaran. Edisi 12. Jilid 1. Manaj Pemasar. Published online 2008.

2. Grönroos C. The relationship marketing process: Communication, interaction, dialogue, value. J Bus Ind Mark. Published online 2004. doi:10.1108/08858620410523981

3. Hill CWL, Jones GR. Strategic Management: An Integrated Approach.; 2007.

4. Robehmed N, Colao JJ. What Is A Startup? Forbes.com. Published online 2013.

5. David FR. Konsep Manajemen Strategis.; 2005.

6. basuki sulistyo. Metode Peneltian. Metod Peneltian. Published online 2006.

7. Dr. Uhar Suharsaputra. M.Pd. Metode Penelitian Kuantitatif, Kualitatif Dan Tundakan.; 2014.

8. Sugiyono. Metode Penelitian Kuantitatif, Kualitatif dan R \& D.Bandung:Alfabeta. Metod Penelit Kuantitatif, Kualitatif dan R DBandungAlfabeta. Published online 2012. doi:10.1017/CBO9781107415324.004

9. Neuman WL. Metode Penelitian Sosial: Pendekatan Kualitatif dan Kuantitatif Edisi Ketujuh. Jakarta PT Indeks. Published online 2013.

10. Emzir. Metodologi Penelitian Pendidikan Kuantitatif \& Kualitatif.; 2017.

11. Rahmat PS. Penelitian Kualitatif. J Equilib. Published online 2009.

12. Prastowo A. Metode Penelitian Kualitatif dalam Perspektif Rancangan. J Fokus Konseling. Published online 2016.

13. Moleong LJ. Metodologi Penelitian Kualitatif, Cet.; 2018.

14. Morissan. Periklanan: Komunikasi Pemasaran Terpadu. Jakarta Prenada Media Gr. Published online 2015.

15. Muslikhah Dwihartanti. Komunikasi Yang Efektif. Staff Site Univ Negeri Yogyakarta. Published online 2004. 